\title{
Semiotics and Discourse Studies
}

Sémir Badira

\begin{abstract}
In this paper, I would like to discuss the contribution that poststructuralist semiotics has brought to the analysis of academic discourse. The semiotic model was developed initially for the analysis of tales and myths. It has been gradually extended to various forms of fiction (novels, short stories), and then, according to "a growing degree of complexity and abstraction", to all "forms of social production of meaning" (GREIMAS; LANDOWSKI, $1979, p .5)$. This is the project stated in the first pages to a book entitled Introduction to Discourse Analysis in Social Sciences, published by Greimas and Landowski in 1979. The generalized extension is based on a typology of discourses that has been illustrated by specific analyses published in the 1980s (BASTIDE, 1981; BASTIDE; FABBRI, 1985; LANDOWSKI, 1986; BORDRON, 1987). One may consider that the research project led by Greimas and Landowski is thus located at the farthest point of development and initial application of the model and it is therefore a test for the narrative hypothesis. In doing so, the semiotic approach took the risk of being confronted with other models of analysis, such as they were elaborated in theoretical frameworks resulting from rhetoric (renewed in the 1950s by Chaim Perelman and his school), pragmatics (cf. PARRET 1983; 1987), sociology of knowledge (from the founding work of Berger $\mathcal{E}$ Luckmann, 1966), or as they relate to other theoretical currents in the language sciences (particularly, in France, the Althusserian discourse analysis). For the discourse in social sciences, these models offer two advantages over that of semiotics: on the one hand, it seems that the theoretical postulates on which they are worked out are more directly in accord with this type of discourse; on the other hand, they can count on a solid tradition of studies to ensure the sustainability of the results. Nevertheless, the model of semiotic analysis is original and it has also an advantage: it is general. I will put forward the benefits of this generality.
\end{abstract}

Palavras-chave: Discourse studies. Semiotic. Academic discourse. Greimas.

a Pesquisador associado sênior do Belgian Fund for Scientific Research-FNRS na Universidade de Liège; E-mail: semir.badir@gmail.com. 
${ }^{1}$ Everyone can see that structuralism is out of favour nowadays, but a lot of so-called "poststructuralist" trends are simply the continuation of structuralist ways of thinking, with some slight theoretical moves. I would have put aside this subtle distinction if semiotics was not, by itself, a sort of interdisciplinary field, with traditions of thought that have almost nothing in common, namely, to be very brief, on the one hand, the structuralist tradition, including the Baltic participation around Lotman's work, and, on the other hand, the Peircian tradition.

${ }^{2}$ The Archaeology of Knowledge: And the Discourse on Language (first published in English in 1972).

${ }^{3}$ Originally published in 1958 in Journal de psychologie, later included in Problèmes de linguistique générale, I (Problems in General Linguistics, vol. 1).

${ }^{4}$ To be precise, there are some utterances of discourse in Saussure's manuscripts, but none of them leads to the building of a theoretical concept (apart maybe from a brief note published in 1996 in Saussure's Écrits de linguistique générale.).

5 "Le discours, considéré comme manifestation du langage".

\section{Introduction: Semiotics and Discourse}

In this study, I would like to discuss the contribution that semiotics has brought to the analysis of discourse, in particular to discourse generally called "scientific" or "academic". First, I will show that semiotics has developed an original theory about discourse. To be more precise, this theory was only prompted by the structuralist trend of semiotics, as it grew in France in the 1960s and early 1970s, then spread beyond France - mainly in Italy, Belgium, the Netherlands, and in the Latin American countries ${ }^{1}$.

Discourse is a major concept introduced in semiotics by Algirdas Julien Greimas in 1966 in his book Structural Semantics (Sémantique structurale). This introduction was made before the use of the concept by Michel Pêcheux (in 1969) or Michel Foucault (also in 1969²), and well before the French translation of Voloshinov's works, Marxism and the Philosophy of Language, which was seminal for discourse analysis in France. His only predecessor is Émile Benveniste, who introduced the concept in linguistics in 1958 in his paper "Subjectivity in Language" ${ }^{\prime 3}$. Ferdinand de Saussure did not use it $^{4}$, Louis Hjelmslev, who had a great influence on Greimas' thought, did not either. Greimas (1966, p. 39) defines discourse in articulation with and opposition to language: "discourse [is] taken as the manifestation of language ${ }^{\prime \prime 5}$ (manifestation is a Hjelmslevian concept).

Later in the book, when Greimas explores what he called "the discursive manifestation" (la manifestation discursive), he proposed a typology of "semantic micro-universes", based on both semantic and syntactical criteria (Fig. 1).

Figure 1 - Typology of semantic micro-universes

\begin{tabular}{|l|c|c|}
\hline \multicolumn{1}{|r|}{ Models } & functional & qualifying \\
MANIFESTATION & & \\
\hline Practical & technological & scientific \\
\hline mythical & ideological & axiological \\
\hline
\end{tabular}

Source: GREIMAS, 1983, p. 128. 
This typology, one of the first of its kind, applies to discourse. It assumes that the analysis of discourse has to be made on a semantic basis, in such a way that four "semantic micro-universes" - named technological, ideological, scientific, and axiological - have distinctive features.

I intend to trace the semiotic argument about discourse. But, before this, I would like to respond to a possible objection. If it is so that semiotics has so much to do with the conceptual development of discourse, how come that it is so little known? Why are, even on the French stage, Foucault, Voloshinov (aka Bakhtin 6 ), or Pêcheux, the relevant reference authors for discourse studies, instead of Greimas? The answer is quite simple: unlike the other authors just mentioned, Greimas, while he was fully active, never emphasized discourse. More crucial in his mind was the concept of meaning. One of Greimas' followers, Jacques Fontanille, did actually entitle a digest of semiotic theory The Semiotics of Discourse (Sémiotique $d u$ discourse, 1999), but he did, quite clearly, when the success of discourse analysis had already grown exponentially. Indeed, semiotics is usually defined as a science of meaning (or as a science of systems of meaning). In this regard, discourse is just a medium, just as pictures, films, music, or architecture are. A science of meaning applies to any medium and does not attempt to provide a description of each individual medium. However, the test of time has shown that this generalization to any medium has found a practical restriction: it is mostly in the arts that semiotics has applied its method, and not really in all "discursive manifestations". So, semiotics and discourse analysis have henceforth had their respective territories- at least in France, and even if there is much overlap and overflow between them. But this was not meant to be that way from the beginning. During the first stage of generalization and expansion, every kind of discourse and every kind of medium interested semioticians. What I would like to do today is to

${ }^{6}$ Marxism and the Philosophy of Language was first attributed to $M$. Bakhtin, then reattributed to its genuine author, Valentin Voloshinov. On this affair, see Bronckart and Broca (2011). review how the semiotic approach to non-artistic discourse, especially discourse in social sciences, was developed, although within certain limits. Simultaneously, we will uncover some of the reasons why semioticians have hesitated to conduct further analysis of non-artistic discourse. 


\section{Semiotic analysis of discourse in social sciences: an overview}

To continue, I will simply propose an overview of semiotic work on discourse in social sciences. This will be organized in two sets:

- Greimas' work;

- Greimas' work in collaboration with other scholars.

\section{Greimas' work}

One can consider, in view of Greimas' work, that semiotics has analysed discourse in social sciences since the very beginning. Indeed, Greimas did not undertake semiotic analysis on the basis of literary texts but on the basis of analytical works applied to those texts. Thus, semiotic analyses were, and they still often are, second-degree analyses. I'll give you some evidence of this:

- In 1963, an article by Greimas about Dumézil's works on ancient myths was published;

- In 1966, the year of publication of Structural Semantics, another article ${ }^{8}$ discusses Lévi-Strauss' work and seeks to rewrite some analyses of a Bororo myth related in The Raw and the Cooked;

7 "La Description de la signification et la Mythologie comparée" ( "C o m p a r a t i ve Mythology").

8“Éléments pour une théorie de l'interprétation du récit mythique".

${ }^{9}$ Originally published as Le Cru et le Cuit in 1964, later translated by John and Doreen Weightman in 1966.

10 “Éléments d'une grammaire narrative" ("Elements of a Narrative Grammar").

${ }^{11}$ Propp's Morphology of the Tale was published in Russia in 1928, translated in English in 1958, and in French only in 1970 . Lévi-Strauss was the first scholar in France to talk about it in 1960 , in a paper entitled "La structure et la forme".
- And in 1969, an article is published on Propp's analyses on Russian folk tales ${ }^{10}$, but Claude Brémond, who also studied Propp's works, recognized since 1964 his debt to a seminar given by Greimas on this matter in the winter of 1963-1964 and mentioned that a cyclostyled draft in which some chapters were devoted to Propp's works had been diffused ${ }^{11}$;

- Finally, I would like to mention the last chapter of Structural Semantics, which is devoted to French novelist George Bernanos' works but only through a study written by Greimas' student Taksin Yücel.

Thus, a part of the job was already done when semiotic analysis is applied. Why is that so? I guess we can credit this to a voluntary distribution of skills: Greimas did not claim to be a mythologist nor a literary scholar; he was a lexicologist, 
12 "Le postulat implicite, sous-jacent à la quête d'une méthode d'analyse sémantique que nous avons poursuivie depuis de nombreuses années, exigeait instamment qu'une telle analyse de discours ne pourrait être considérée comme fondée que si ses procédures étaient applicables à l'élucidation de n'importe quel discours."

13 “[...] que si les modèles que l'on pouvait proposer étaient susceptibles de rendre compte des modes de production, d'existence et de fonctionnement de n'importe quel texte". specialized in semantic matters. He needed sources, scientific sources, to apply his semiotic analyses. But this does not mean that his semiotic analyses focused on scientific discourses for their own sakes. Only the objects of those scientific discourses were exploited. That is why I consider these semiotic analyses as second degree analyses. And yet, they are close to what we are looking for: same texts, same kind of analyses; only the focus changes: the objects of the discourse, on the one hand, the discourse itself, on the other hand.

The next book written by Greimas, though it is a collection of articles, is, this time, entirely devoted to the analysis of academic discourse. Semiotics and Social Sciences (Sémiotique et sciences sociales), published in 1976, opens with a long introduction entitled "On scientific discourse in social sciences". It tackled the problem that scientific discourse presents to semiotic analysis. This problem has two faces: one is to establish the conditions of a semiotic approach to science discourse, that is, the suitability of semiotic analytical concepts for this new object; the other is, beyond that suitability, to justify the relevance of the semiotic approach.

I will talk about the second part of the problem - the "why" - before offering some clues about the first part concerning the "how".

So, why bring new objects to semiotics? Because semiotics is a general theory, and is an empirical one. Generalization needs to be tested, over and over again, in a spreadable world:

The implicit postulate underlying the quest for a method of semantic analysis that we have pursued for many years urged that such discourse analysis could only be considered justified if its procedures were applicable to the interpretation of any kind of discourse. (GREIMAS, 1976, p. 79) $)^{12}$

And why does this also contribute to discourse studies? The rest of this quote gives us the answer: "[...] [and] if the models that one can propose were capable of reporting on the modes of production, existence and functioning of any text" (GREIMAS, 1976, p. 79)

To highlight his semiotic models, Greimas did not hesitate, in the conclusions of an interdisciplinary meeting dedicated to "ethnic literature" (i.e. oral non-western literature), which was at that time a new area of studies, to criticize scholars' works 
14 "Ceci me semble un bon exemple d'analyse textuelle qui, tout en restant juste et fine, ne permet pas, à cause de son parti-pris inductif, de rejoindre le niveau de grammaire narrative de surface à partir duquel la beffa de Boccace paraîtrait comme la manifestation spécifiant un programme narratif canonique".

15 "Le travail de Paolo Ramat se présente comme une analyse linguistique irréprochable, tout en paraissant du point de vue sémiotique, inachevée : il lui manque le modèle structurel subsumant l'ensemble d'analyses particulières et rendant compte de toutes les manifestations".

${ }^{16}$ As Greimas did in "La soupe au pistou: ou la construction d'un objet de valeur", published in 1979 (translated as "Problems of Narrative Semiotics: Objects of Value" in 1987). under the assumption that they did not succeed in describing the "mode of functioning" of their objects. On Cesare Segre's analysis about Boccace's sources, he said:

This seems to me a good example of a textual analysis which, while remaining right and precise, does not allow one, on account of its inductive bias, to reach the level of surface narrative grammar from which Boccaccio's beffa would appear as the manifestation specifying a canonical narrative program. (GREIMAS, 1976, p. 200) $)^{14}$

And just after this, against Paolo Ramat's study:

Paolo Ramat's work presents itself as an irreproachable linguistic analysis, while it appears from a semiotic point of view, incomplete: it lacks the structural model subsuming the whole range of particular analyses and accounting for all manifestations. (GREIMAS, 1976, p. 200) $)^{15}$

So, whether a literary scholar or a linguist, you miss the point if you do not succeed in reaching the right level at which your description can be generalized. This is a major semiotic principle.

Now that the "why" has been made clear, let's turn our attention to the "how". How can semiotic analysis be applied to science discourse? We have already seen that semiotic analysis had first been applied to myths, folk tales and novels, even though they did it through the prism of other readings. These kinds of texts have obviously something in common: they are all narratives. The next challenge was to apply an analytical tool originally built for narratives to discourse which is not usually taken as a narrative. This new goal implied fulfilling one condition.

To transcend its narrative origin, the semiotic methodological tools needed to be based on a deeper conceptual level. This elementary level is that of predicative syntax. From this point of view, whenever a process can be read as one manifesting some action, there is, not a narrative yet, but a narrative sketch. Take, for instance, a recipe ${ }^{16}$. It has a narrative schema, even it is not a narrative. There are indeed some actions implied in a recipe, and these actions are arranged in a specific order; so there is also an action process. At this elementary level of analysis, there is no need to make 
a distinction between narrative texts and non-narrative texts, although analysis tends to turn the text into a narrative.

The main features of the semiotic analysis about science discourse are fourfold:

- The subject of the action process in science may be not present, partially or totally, in the text. The reason of this is that most of the subject's actions are speech acts. Thus, the scientist is the narrator as well as the "hero" of his text (GREIMAS, 1976, p. 10).

- Speech acts in science lead to a taxinomic process, naming and organizing the world (GREIMAS, 1976, p. 14).

- The "quest" of the scientist, by naming and organizing the world, is always assertive: it is about speaking the truth, i.e. a "veridiction". The scientist's means are arguments making sense in a rational isotopy (GREIMAS, 1976, p. 20).

- In addition to naming and organizing the world discursively, the scientist has to convince the reader that he speaks truly. Thus he is not only the "hero" of the action process. He is also the "sender" of the quest, while the reader is the "receiver". Between them an "enunciative contract" must be concluded. For that reason, the text is also ruled by communication strategies (GREIMAS, 1976, p. 24).

Of course, at that early stage, those theoretical features were hypotheses to be tested. This is where the semiotic community was called on. So I turn to the next step of this overview.

\section{Greimas's works in collaboration with other scholars}

Three years after the publication of Semiotics and Social Sciences, Greimas edited, with Éric Landowski, a collection to which many semioticians of his seminar collaborated, so that the volume is representative of the semiotic work of the School of Paris. The title of this book is Introduction to Discourse Analysis in Social Sciences (Introduction à l'analyse du discours en sciences sociales). It was published in 1979 , the same year as the Dictionary 
(written in collaboration with Joseph Courtés) ${ }^{17}$, one of the most influential works of this semiotic trend. The foreword of the Introduction told us the same thing I just presented:

- Semiotics came from a double heritage, structural linguistics and folk and myth studies;

- In the 1960s semiotics became autonomous by the way of a theoretical generalization and of the establishment of a general method;

- The first applications of the semiotic method were in the literary field;

- And then expanded to "non-literary discourse, i.e., religious, philosophical, juridical or socio-political" (GREIMAS; LANDOWSKI, 1979, p. 5).

The book's title was chosen to illustrate this last stage, and it contains empirical studies. Those studies had three types of objects, even if those objects can be studied all together:

- A given text (always in French); however, due to the meticulous aspect of the method, only a small passage is extracted from a larger text, article or book; for instance, the foreword of Dumézil's Birth of Archangels (Greimas), two quotes of Mauss' Gift (Geninasca), an article by the historian Lucian Febvre (Giroud), or the conclusive passage of Bachelard's Applied Rationalism.

- With the given text, the author may claim that their analysis also reach a more general object, as a genre or a discursive type, such as "scientific discourse" (as did Darrault, from an analysis of the first paragraphs of Barthe's S/Z), "literary criticism" (as Alexandrescu proposed from two famous critics' studies, the Swiss Jean Starobinski and the French Georges Poulet), or "biblical commentary" (Panier).

- But one can doubt if this general object is a "discursive type"; they can also consider that the generalization of the object of the analysis focuses on a disciplinary field, as Landowski (1986) did, with an analysis of the law, taken as a whole social practice of knowledge. 
18 "Elle [la démarche scientifique] obéit tout simplement au schéma narratif (compétence, performance, sanction)". For a short presentation of the narrative schema, see Hébert (2006a).

19 "Il faut supposer que les articles scientifiques sont construits comme les contes merveilleux : au début de l'histoire, il $\mathrm{y}$ a un problème que nous appelons 'manque': à la fin, grâce aux performances du héros, le manque est comblé".

20 "Ce n'est pas en surface que cette formulation prétend trouver son application : la législation n'est pas un roman".

21 "La structure actantielle est difficile à démêler car le 'Je' y tient tous les rôles". 22 "Bien qu'il puisse sembler surprenant de parler de situation polémique dans le cas d'une observation [...]".

23 "La première 'épreuve' ( par commodité, nous gardons cette dénomination $[\ldots]$ ".
The general hypothesis that guided the contributions of this book was that scientific discourse in social sciences is constantly narrative. This was explicitly stated, elsewhere, by Éric Landowski $(1985$, p. 8): “The scientific approach simply obeys the narrative schema (competence, performance, sanction)"18; and also by Bastide and Callon (1985, p. 14): "We must assume that scientific articles are constructed like fairy tales: at the beginning of the story there is a problem that we call 'lack': in the end, thanks to the hero's performances, the lack is filled"19.

And yet, semioticians were aware that this hypothesis is not risk-free. The texts always offered an obvious resistance to it. I would like to quote two semioticians who were actively involved in non-literary discourse analysis. Landowski (1986, p. 13): "It is not at the surface that this formulation claims to find its application; legislation is not a novel"20. Bastide (1981, p. 15), in a series of small concessive clauses: "the actantial structure is hard to unravel, since the 'I' holds all the roles"21; "although it seems surprising to speak of a 'polemical situation' in the case of an observation" (BASTIDE, 1981, p. 20)22; "the first 'proof' (for convenience' sake we keep that term)" (BASTIDE, 1981, p. 20) ${ }^{23}$.

From a broader perspective, semiotic theory could prove defective in its attempt at generalization. Its analytical model addresses texts at three levels:

- The level of discursive surface, in which rhetorical figures, among other things, are analysed;

- The narrative level, in which the elements of the action process are analysed;

- And the elementary semantic level, in which the main isotopies are connected in such a way that the narrative dynamics can be described.

But the second level is a problem. Why impose a narrative level on any text? Could we consider, for some cases more profitably, an "argumentative" level? Furthermore, would an "argumentative" level be irreducible to the "narrative" schema? Two answers were given to this objection.

The first answer is a "yes", but I should add that it is an unorthodox reply. So you have to read between the lines. It 
24"Dans une perspective actantielle les [techniques discursives] seront autant d'adjuvants ou d'opposants dont l'énonciateur [métadiscursif] a besoin au cours de son argumentation. [...] Nous allons considérer par la suite les différents gestes rhétoriques de l'énonciateur comme faisant partie d'un discours rhétorique généralisé".

25 "Programme cognitif et programme pragmatique s'articulent au point où un même acteur assume simultanément les rôles actantiels de sujet réalisé d'un faire cognitif et de donateur d'un /vouloir/ (régi par le savoir précédemment acquis) à l'intention d'un acteur collectif, le donataire, sujet virtuel d'un faire juste, positivement valorisé"

26 "Le sujet épistémique I est ici le destinateur d'une nouvelle communication, dans laquelle il assume la position d'un sujet du faire persuasif, dont l'objet, ainsi que le destinataire, sont différents de ceux de la première communication. [...] [Le sujet épistémique II possède] une compétence qui lui est attribuable en tant qu'énonciataire et qui lui permet [...] de reconnaitre la finalité de l'argumentation à partir de la disposition générale du discours [...] : c'est alors une compétence proprement narrative". took into consideration that argumentation could substitute for the narrative level. This hypothesis is suggested by Sorin Alexandrescu:

In an actantial perspective, discursive techniques will be as helpers or opponents that the metadiscursive enunciator needs in the course of his argument. We shall then consider the different rhetorical gestures moves? acts? of the enunciator as part of a generalized rhetorical discourse. (ALEXANDRESCU, 1979, p. 211-212)24

Greimas himself gave another answer and, basically, it is a "no". The argumentative parameters can "complicate" - a lot the narrative program, leading some actants to occupy multiple functions at once, but the narrative frame is preserved. This answer looks as the "official" one, since inner circle semioticians had made it their own. See, for instance, Geninasca:

A cognitive program and a pragmatic program articulate to the point where the same actor simultaneously assumes the actantial roles of the realized subject of a cognitive act and of a donor of a 'will' (governed by the knowledge previously acquired) for a collective actor, the donee, a virtual subject of a fair act, positively valued. (GENINASCA, 1979, p. 101) ${ }^{25}$

If you have not immediately understood the quote, do not worry: neither did I! It is complicated and quite jargony. All I know, and that is the only thing we need to decipher, is that by "cognitive program" the author pointed out a narrative, and by "pragmatic program" he referred to argumentation.

Same kind of distribution between argumentative and narrative action in the following quote from Jean-Marie Floch:

The epistemic subject I is here the sender of a new communication in which he assumes the position of a persuasive subject whose object as well as receiver are different from those of the first communication. [...] [The epistemic subject [demonstrates] a competence as a discourse addressee which allows him [...] to recognize the purpose of the argumentation from the general disposition of the discourse [...]: it is then a properly narrative competence. (FLOCH, 1979, p. 185) $)^{26}$

In a paper published in 1987, Herman Parret advocated reconciliation between semiotics and pragmatics. As he said, "it cannot be too optimistic, I believe, to evoke the possible 'pragmatic turn of semiotics' on the one hand, and the 'semiotic 
turn of argumentative theory' on the other" (PARRET, 1987, p. 171). The so-called "pragmatic turn of semiotics" recognised what semioticians had been trying to do for a decade: by "complicating" the method, and by introducing the speaker as an actual actant of the discursive process. But the "semiotic turn of argumentative theory", as suggested by Parret, might look bizarre at first glance. It would come down to doing what semioticians study in the Introduction to Discourse Analysis in Social Sciences: to "look at an argumentative-scientific discourse as a narrative" (PARRET, 1987, p. 173). Why would a pragmatic philosopher do that? Let's read the first lines of Parret's thought about that:

Let me present five aspects that could justify such an approach. First of all, narratological analysis demonstrates that scientific and philosophical discourse[s] are argumentative. This seems maybe trivial. However, we should not forget that many philosophers and scientists still have the traditional 'metaphysical' idea that their discourse is purely descriptive [...]. (PARRET, 1987, p. 173)

The next four reasons revolved around the same basic statement: semiotics reveals argumentativity; it has the right method for this, even if its general hypothesis is not made for argumentative discourse but for narratives. Its method is a linguistic one. So that is what semiotics brought to pragmatics: the skills and goals of a linguistic method.

Let's go back to the "pragmatic turn of semiotics". Whether integrating argumentation to the narrative model or splitting the semiotic model into two, one narrative and the other rhetoric, the irreducible specificity that argumentation brought is reflexivity, which is essential to argumentative discourse, and conversely incidental in narratives. Reflexivity cannot be properly included into an "algorithm of actions". In other words, reflexivity cannot be governed by the same rules as those that link actions together, as, in generative grammar, logical rules link words together in a sentence. Worse still, reflexivity can cause the narrative algorithm to malfunction.

This was clearly observed by semioticians. For example, $\mathrm{J}-\mathrm{Cl}$. Giroud incisively noted about the discourse of history that:

If the task of organization could be described as a sequence of actions, the elements to be organized themselves, the places into which the historian's work delves, are dependent 
${ }^{27}$ Si la tâche d'organisation a pu être décrite comme une suite d'opérations, les éléments mêmes à organiser, les lieux sur lesquels s'attarde le faire de l'historien sont dépendants d'un ultime personnage que l'on peut désigner comme la "société". [...] L'histoire n'est plus seulement l'objet du discours de l'historien, elle est aussi l'objet, en quelque sorte, d'un discours "social".

28 "L'examen du texte de Georges Dumézil a permis de nous faire une idée quant aux rapports complexes qu'entretient le discours de la recherche, qui tend à tout prix - ruse et vocation en même temps - à se faire passer pour un discours objectif et sociolectal dont le sujet serait un actant à la fois collectif et quelconque et où le chercheurlocuteur ne serait que l'acteur délégué, avec le discours de la découverte, $n$ é c e s s a i r e m e n t personnalisé, mais inscrit, nous avons pu l'entrevoir, dans un algorithme sous-jacent qui le régit en sous-main. Relations paradoxales entre le discours social qui n'arrive pas à cacher ses attaches à l'énonciateur singulier qui le produit et le discours individuel qui se laisse guider par une finalité qui le dépasse". on an ultimate character that one may define as 'society'. [...] History is no longer merely the object of the historian's discourse; it is also, as it were, the object of a 'social' discourse. (GIROUD, 1979, p. 138-139)27

Greimas himself had clearly identified this impurity of discourse in social sciences, always balanced between the idiolectal and the sociolectal:

The examination of Georges Dumézil's text gave us an idea of the complex relations between the discourse of research, which tends at all costs - a ruse and a vocation at the same time - to pass as an objective and sociolectal discourse (in which the subject would be an actant that is both collective and arbitrary, and the researcher-speaker only the delegated actor), and the discourse of discovery, necessarily personalized, but making part, as we have seen, of an algorithm underlying it. Paradoxical relations between the social discourse that cannot hide its attachments to the singular speaker who produces it and the individual discourse that is guided by a finality that goes beyond it. (GREIMAS, 1979, p. 60) ${ }^{28}$

The studies contained in the Introduction show that the historian, the art historian, the political scientist, the anthropologist, the philosopher or the literary critic, even if they are the heroes of the "quest for certainties", also carry the uncertainty about the meaning of this quest, and this is not a light burden. The discourse in social sciences comes with its own interpretation.

\section{Conclusion}

After Greimas' death, in 1992, major changes were brought to the semiotic field. All of them point to the abandonment of narrativity. Not that the narrative model has been invalidated, but it was no longer the core of the semiotic project. Ironically, this was also the end of the discussion about argumentativity, as an integrated part of or alternative to narrativity. Yet, literary texts, and even non-narrative texts, such as scientific texts, continued to be studied and analysed, but on other grounds than the narrative model. One could say that argumentativity undermined the narrative hypothesis and instead reorientated semiotic research towards other theoretical targets: the analysis 
${ }^{29}$ See in particular Claude Zilberberg's works. For an English presentation, see Hébert (2006b).

${ }^{30}$ Initiated by Fontanille (1989).

31 Initiated by Éric Landowki (1989).

${ }^{32}$ See Bordron (2011). of the sensible in the Kantian sense ${ }^{29}$, enunciation and discourse $\operatorname{acts}^{30}$, discursive interactions ${ }^{31}$, and discursive iconism ${ }^{32}$.

What were the implications of these changes for the relationship between semiotics and discourse studies? Well, the links between them were distorted when they no longer had objects in common, or even objects that would realistically be shared. Narrativity and argumentativity were those common objects that could be included into a theory of meaning as well as into a theory of discourse. From now on, discourse is part of the semiotic concepts, and no doubt meaning is also in use in discourse studies. But the theories do not really meet, for lack of a common purpose.

\section{REFERENCES}

ALEXANDRESCU, S. La critique littéraire : métadiscours et théorie de l'explication. In: GREIMAS, A.J.; LANDOWSKI, É. (Eds). Introduction à l'analyse du discours en sciences sociales, Paris: Hachette, 1979. p. 211-212.

BASTIDE, F. La démonstration. Analyse de la structure actantielle du faire-croire. Actes Sémiotiques - Documents de recherche, 28, 1981, p. 15.

BASTIDE, F.; CALLON, M. À la découverte des découvertes. In: ; FABBRI, P. (eds.). Les procédures de découverte. Actes sémiotiques - Bulletin de recherche, 33, 1985, p. 14.

BENVENISTE, E. Subjectivity in Language. In: Problems in General Linguistics, vol. 1. Translated by Mary Elizabeth Meek, Coral Gables, Florida: University of Miami, 1971: 223-230.

BERGER, P.L.; LUCKMANN, T. The Social Construction of Reality: A Treatise in the Sociology of Knowledge. Open Road Media, 2011.

BORDRON, J-F. Descartes: Recherches sur les contraintes sémiotiques de la pensée discursive. Presses Univ. de France, 1987. L'iconicité et ses images. Paris: Presses Universitaires de France, 2011. 
BRONCKART, J-P; BROCA, C. Bakhtine démasqué. Histoire d'un menteur, d'une escroquerie et d'un délire collectif. Genève: Librairie Droz, 2011.

FLOCH, J-M. Communication ou manipulation? In: GREIMAS, A.J.; LANDOWSKI, É. (eds). Introduction à l'analyse du discours en sciences sociales, Paris: Hachette, 1979. p. 185.

FONTANILLE, J. Les espaces subjectifs. Introduction à la sémiotique de l'observateur. Paris: Hachette, 1989.

Sémiotique du discours. Limoges: Pulim, 1999.

FOUCAULT, M. The Archaeology of Knowledge: And the Discourse on Language. Translated by Alan Sheridan. New York: Vintage Books, 1982. First English edition: 1972.

GENINASCA, J. Interpréter, persuader, transformer. In: GREIMAS, A.J.; LANDOWSKI, É. (eds). Introduction à l'analyse du discours en sciences sociales, Paris: Hachette, 1979. p. 101.

GIROUD, J.-Cl. Apologie pour l'historien. In: GREIMAS, A.J.; LANDOWSKI, É. (eds). Introduction à l'analyse du discours en sciences sociales, Paris: Hachette, 1979. p. 138-139.

GREIMAS, A.J. Comparative Mythology. In: On Meaning: Selected Writings in Semiotic Theory. Translated by Frank Collins and Paul Perron. Minneapolis: University of Minnesota Press, 1987, p. 3-16.

. Des accidents dans les sciences dites humaines. In: ; LANDOWSKI, É. (eds). Introduction à l'analyse du discours en sciences sociales, Paris: Hachette, 1979. p. 60.

Éléments d'une grammaire narrative. L'Homme, IX-3, pp. 71-92, 1969.

. Elements of a Narrative Grammar. In: . On Meaning: Selected Writings in Semiotic Theory. Translated by Frank Collins and Paul Perron. Minneapolis: University of Minnesota Press, 1987, p. 63-83. 
GREIMAS, A.J. Éléments pour une théorie de l'interprétation du récit mythique. Communications, 8, 1966.

La Description de la signification et la Mythologie comparée. L'Homme, Vol. 3-3, pp. 51-66, 1963.

La soupe au pistou: ou la construction d'un objet de valeur. Actes sémiotiques - Documents de recherche, 5, 1979.

. Problems of Narrative Semiotics: Objects of Value. In:____. On Meaning: Selected Writings in Semiotic Theory. Translated by Frank Collins and Paul Perron. Minneapolis: University of Minnesota Press, 1987, p. 84-105.

Sémantique structurale. Paris: Larousse, 1966.

. Sémiotique et sciences sociales. Paris: Seuil, 1976.

Structural Semantics: An Attempt at a Method. Translated by Daniele McDowell, Ronald Schleifer, and Alan Velie. Lincoln, Nebraska: University of Nebraska Press, 1983.

; COURTÉS, J. Semiotics and Language: an Analytical Dictionary. Translated by Christ Larry, Patte Daniel, Lee James, McMahon Edward II, Phillips Gary, \& Rengstorf Michael. Bloomington, IN: Indiana University Press, 1983.

; LANDOWSKI, É. (Eds). Introduction à l'analyse du discours en sciences sociales, Paris: Hachette, 1979.

HÉBERT, Louis. The Canonical Narrative Schema. Signo [online]. Rimouski (Quebec), 2006a. Available at: <http://www. signosemio.com/greimas/canonical-narrative-schema.asp >.

The Tensive Model. Signo [online], Rimouski (Quebec), 2006b. Available at: <http://www.signosemio.com/fontanille/ tensive-model.asp $>$.

LANDOWSKI, É. La part des choses. In: BASTIDE, F.; FABBRI, P. (Eds.). Les procédures de découverte. Actes sémiotiques - Bulletin de recherche, 33, 1985, p. 8.

Seuil, 1989.

- La société réfléchie. Essais de socio-sémiotique. Paris: 
LANDOWSKI, É. Pour une approche sémiotique et narrative du droit. Actes Sémiotiques - Documents de recherche, 71, 1986.

PARRET, H. Argumentation and Narrativity. In: VAN EEMEREN, F; GROOTENDORST, R; BLAIR, J.A.; WILLARD, C. (Eds.). Argumentation: Across the Lines of Discipline, DordrechtProvidence: Foris Publications, 1987, Volume I, p. 171.

Semiotics and Pragmatics: An Evaluative Comparison of Conceptual Frameworks. John Benjamins Publishing, 1983.

PÊCHEUX, M. Analyse automatique du discourse. Paris: Dunod, 1969.

SAUSSURE, F. Écrits de linguistique générale, Paris: Gallimard, 1996.

Writings in General Linguistics. English transl. by Carol Sanders \& Matthew Pires. Oxford University Press, 2006.

VOLOSHINOV, V.N. Marxism and the Philosophy of Language. Reprint edition. Cambridge, Mass: Harvard University Press, 1986. 


\section{Resumo}

\section{Semiótica e Estudos do Discurso}

Neste artigo, eu gostaria de discutir a contribuição que a semiótica pós-estruturalista deu à análise do discurso acadêmico. O modelo semiótico foi desenvolvido inicialmente para as análises de fábulase mitos. Ele tem sido gradualmente estendido às várias formas de ficção (romances, contos) e, então, de acordo com "um grau de crescimento de complexidade e abstração", para todas as "formas de produção social de sentido" (GREIMAS; LANDOWSKI, 1979, p. 5). Este é o projeto declarado nas primeiras páginas de um livro intitulado Introdução à Análise do Discurso nas Ciências Sociais, publicado por Greimas e Landowski em 1979. A extensão generalizada toma como base uma tipologia de discursos que tem sido ilustrada por análises específicas publicadas nos anos 1980 (BASTIDE, 1981; BASTIDE; FABBRI, 1985; LANDOWSKI, 1986; BORDRON, 1987). Pode-se considerar que o projeto de pesquisa liderado por Greimas e Landowski está então localizado no ponto mais distante do desenvolvimento e aplicação inicial do modelo e, portanto, é um teste para a hipótese narrativa. Ao fazê-lo, a abordagem semiótica correu o risco de ser confrontada com outros modelos de análises, tais como foram elaborados na perspectiva teórica resultante da retórica (renovada nos anos 1950 por Chaim Perelman e sua escola), da pragmática (cf. PARRET, 1983; 1987), da sociologia do conhecimento (pelo trabalho fundador de Berger E Luckmann, 1966), ou como elas se relacionam com outras correntes teóricas nas ciências da linguagem (em particular, na França, a análise do discurso althusseriana). Quanto ao discurso nas ciências sociais, esses modelos oferecem duas vantagens sobre a semiótica: por um lado, parece que os postulados teóricos nos quais são trabalhados estão diretamente de acordo com esse tipo de discurso; por outro lado, eles podem contar com uma sólida tradição dos estudos para garantir a sustentabilidade dos resultados. Mesmo assim, o modelo de análise semiótica é original e tem também uma vantagem: ela é geral. Apresentarei os beneficios dessa generalidade.

Keywords: Estudos do Discurso. Semiótica. Discurso acadêmico. Greimas. 